\title{
The Value Relevance of Sustainability Reporting: Comparison between Malaysia and Indonesia Stock Market
}

\author{
NANIES PUTRI HALIMAH* \\ ALFIANA IRSYANTI \\ LUTFI ROHMAH AINI \\ Universitas Gadjah Mada
}

\begin{abstract}
This study aims to investigate whether information content on sustainability reporting has a significant association with listed companies' share price. We also assess the differential effect of sustainability reporting adoption in the mandatory and voluntary context in developing countries, particularly in Malaysia and Indonesia, for several reasons provided. The final sample was 43 firms in Indonesia and 57 firms in Malaysia. The data in this study used secondary data obtained from Thomson Reuters Datastream. To examine our hypothesis, we apply the regression model. This study provides evidence that information on sustainability reporting has a significant association with the firm's price. This shows that sustainability reporting is relevant because it can make a difference in the user's decision and is measured reliably enough to reflect the value of equity. Another result of this study is that sustainability reporting's value relevance is more robust in the Malaysian stock market than in the Indonesian stock market.
\end{abstract}

Keywords: sustainability reporting; value relevance; signaling theory

\begin{abstract}
Abstrak: Penelitian ini bertujuan untuk menginvestigasi apakah konten informasi dalam pelaporan keberlanjutan memiliki hubungan yang signifikan terhadap harga saham perusahaan terdaftar. Penelitian ini juga mengujji perbedaan efek adopsi pelaporan keberlanjutan dalam konteks wajib dan sukarela di negara-negara berkembang, terutama di Malaysia dan Indonesia atas dasar beberapa alasan yang peneliti berikan. Sampel akhir penelitian ini adalah 43 perusahaan di Indonesia dan 57 perusahaan di Malaysia. Data yang digunakan dalam penelitian yakni data sekunder yang diperoleh dari Thomson Reuters Datastream. Pengujian hipotesis dilakukan dengan menerapkan model regresi. Hasil penelitian menunjukkan bukti bahwa informasi tentang pelaporan keberlanjutan memiliki hubungan yang signifikan dengan harga perusahaan. Hal tersebut berarti bahwa pelaporan keberlanjutan mengandung informasi yang relevan karena dapat membuat perbedaan dalam keputusan pengguna dan diukur cukup andal untuk tercermin dalam nilai ekuitas. Hasil lain dalam penelitian ini, relevansi nilai pelaporan keberlanjutan lebih kuat di pasar saham Malaysia daripada di pasar saham Indonesia.
\end{abstract}

Kata Kunci: laporan berkelanjutan; relevansi nilai; teori signaling

*Corresponding author: naniesputri@gmail.com 


\section{Introduction}

We examine whether information content on sustainability reporting is reflected in listed Malaysia and Indonesia companies' equity market value. Our research is conducted in those countries to represent a different context: mandatory and voluntary adoption. A large number of studies have examined the value relevance of information on company disclosure, whether it is financial information (e.g., Hellstrom, 2006; Nijam and Jahfer, 2018; Kerr, 2019) and/or non-financial information such as sustainability reporting (e.g., Narullia and Subroto, 2018; Sutopo et al., 2018; Cortesi and Vena, 2019). However, some studies are mostly confined only to one context, mandatory or voluntary. No study compares the value relevance of sustainability reporting between both of them. This study's fundamental question is whether or not the mandatory and voluntary sustainability reporting adoption impacts equity market value differently. Therefore, we are motivated to assess the difference of value relevance on mandatory adoption or voluntary adoption of that reporting.

Theoretical studies suggest that the primary purpose of conducting test value relevance is to extend our knowledge regarding the relevance and reliability of particular accounting amounts as information used by an investor to value a firm's equity (Barth et al., 2001). That purpose is consistent with the inputs-to-equity valuation theory. In one of $\mathrm{HW}$ paper, the state that the role of accounting is to provide information that investors use as an input to valuations models in valuing firms' equity (Holthausen and Watts, 2001). Furthermore, over the last decades, the amount of information that companies disclose has increased significantly. They disclose not only financial information as it reflects in the financial statement but also non-financial information. Consequently, that phenomenon leads to a new method to integrate this information into one reporting called integrated reporting or sustainability reporting (Cortesi and Vena, 2019).

We examine the value relevance in developing countries, particularly in the context of Malaysia and Indonesia. Accordingly, we expect that the information cont-ent on sustainability reporting can be value relevant in Malaysia and Indonesia context. Besides that, Malaysia has already regulated sustainability reporting as a 
mandatory report for all listed companies as of December 31, 2018 (Based on Malaysia Sustainability Reporting Guide), meanwhile Indonesia still adopt it as voluntary disclosure except banking industry as of January 1, 2019 (Based on POJK No. 51/ POJK.03/2017). Therefore, we also expect that the effect of sustainability reporting on equity market value between Malaysia and Indonesia listed companies would be different.

To investigate whether sustainability reporting can be value relevant, we estimate the equation which contains earnings per share, book value, esg score, respectively of the company as a regressor and share price observed three months after the end of the fiscal period the dependent variable. We collect firm-level data about sustainability reporting adoption in 2019, hence obtaining 100 listed adopters (non-financial companies with sustainability reporting). The year 2019 represents the base level of sustainability reporting as a mandatory report in Malaysia, meanwhile still voluntarily in Indonesia. To test our hypotheses, we conduct regression analyses using the value relevance model developed by Ohlson (1995) with modification following to Cortesi and Vena (2019). That information is typically deemed value-relevant if its estimated regression coefficient is significantly different from zero (Holthausen and Watts, 2001).

We find empirical evidence to support that sustainability reporting has a significant relation with the share price. In other words, sustainability reporting is relevant as it makes differences to the user's decision and is measured reliably enough to be reflected in equity values (Barth et al., 2001). Furthermore, we find evidence that there is a different association between information content on sustainability reporting with share price in the mandatory disclosure and voluntarily disclosure context. The information is more relevant in a mandatory context since the reporting content might be more complete as a GRI requires.

Our study's empirical results make an essential contribution to whether the information contained in sustainability reporting is valuable for investors in the firms' value creation process. Our study contributes to the literature on value relevance and sustainability reporting. We contribute to this literature by updating the value 
relevance of sustainability reporting adoption in a different context: mandatory and voluntary. Further, to the best of our knowledge, our study is the first one that assesses the value relevance of sustainability reporting in the Malaysian stock market when it is regulated as a mandatory report.

The rest of our paper is organized as follows. In Section 2, we provide an overview of sustainability reporting and value relevance literature and hypotheses development of this research. In Section 3, we demonstrate how the data, sample, and research methodology will investigate the hypotheses. Further, in Section 4, we report the empirical results and their discussion. In the final section, we present a summary and conclusions, including the study's limitations and suggestions for future research.

\section{Theoretical Framework and Hypothesis Development.}

\subsection{Signaling Theory}

Signaling theory explains why firms have an incentive to report more information to the capital market than is demanded. That information can relate to any aspect of the firm, including financial, strategy, and non-financial aspects of quality (Cotter and Najah, 2011). Companies signal certain information to investors to show that they are better than other companies in the market to attract investments and enhance a favorable reputation (Verrecchia, 1983). Therefore, High-quality firms have a motivation to signal their quality by disclosing their performance (through Sustainability Reporting), which is reflected in a higher market value. Moreover, the high quality of sustainability reporting would increase transparency between firm insiders and other stakeholders and reduce stakeholder's uncertainty regarding the firm's future economic performance (Bachoo and Wilson, 2013).

\subsection{The Value Relevance}

Amir, Harris, and Venuti (1993) were the first researchers to use the term "value relevance" in the literature. Barth et al. (2001), based on SFAC No.5, explains that the amount of accounting is relevant if it can make a difference in the decisions of users of financial statements; accounting numbers can be relied upon if they represent what is intended to be represented. Based on the definition set forth by Francis and Schipper 
(1999), it explains that value relevance can be interpreted as a statistical association between accounting information and company value or stock returns, so value relevance can be used to capture or summarize information that affects the stock price or stock return.

From the perspective of investors, Hellstrom (2006) explains that relevant information is information that contributes to their equity investment decisions and provides a perspective on value relevance that explains the existence of a relationship between the company's market value and financial reporting information that is also in line with Barth et al., (2001) which states that the relevance of accounting information is reflected in the return of stock or company value when investors feel useful benefits. Research that discusses the usefulness of financial information related to investment decision making often uses the term "study of the relevance of accounting information values" because accounting information is considered to be very relevant in determining the intrinsic value of shares and investment decision making as reflected in stock market prices (Sutopo et al., 2018).

Ball and Brown (1968) is a researcher who started research on the usefulness of accounting information until later developed by other researchers to date, such as research conducted by Sutopo et al. (2018), explains that the relevance of EPS values for sustainability reporting award (SRA) companies are higher than for non-SRA companies. Meanwhile, the relevance of BVPS values for SRA companies is lower than non-SRA companies. Kuzey and Uyar (2017) found that sustainability reporting drives value in Turkey. This finding indicates that sustainability reporting is value relevant. Besides that, Cortesy and Vena (2019) states that in assessing the quality of Disclosure, as the relevant integrated reporting (IR) value, can infer higher quality information disclosed, IR heterogeneously influences the relevance of revenue value and book value, increasing disclosure through IR results in higher returns slightly decreased.

\subsection{Sustainability Reporting}

We define sustainability reporting based on the Global Reporting Initiative Standard (GRI) as the practice of measuring, disclosing, and being accountable to 
internal and external stakeholders for organizational performance towards the goal of sustainable development. GRI is the most well-known guideline for sustainability reporting. GRI helps businesses and governments worldwide understand and communicate their impact on critical sustainability issues such as climate change, human rights, governance, and social welfare. This enables concrete action to create social, environmental, and economic benefits for all people (GRI, 2019).

Since the end of the 1990s, sustainability reporting has become an increasingly relevant topic in business and academia (Hahn et al., 2013). Tarquinio et al. (2018) highlighted the importance of guarantees, country lists, industries, company size, and profitability for explaining the disclosure of corporate sustainability reports in Greek, Italian, and Spanish companies. Gonzalez et al. (2018) noted Europe's dominant role, followed by Asia; conversely, North America lags in implementing GRI, and its influence is limited. China and Japan lead the implementation of GRI and affect the entire region. India lags behind other countries in the region, which shows the need for mechanisms to pressure companies to be more sustainable.

Meanwhile, several studies discussed the value relevance of voluntarily nonfinancial disclosures (including sustainability reporting). Loh et al. (2017) found that the better the sustainability reporting quality, the stronger the value relevance. Furthermore, research conducted by Lourenco et al. (2014) provides evidence that market valuations of net income are higher for companies that have a reputation for sustainable leadership, which means that the The reputation of the Company's Sustainability Performance helps investors better evaluate the value of the market company. Aras et al. (2018) showed that non-financial information could also influence investor preferences.

However, most of the previous studies related to the relevance of sustainability reporting are primarily dominated by studies with the scope of developed countries (Kuzey and Uyar, 2017), such as research in the United States, European Countries, Canada, and Australia (Lourenco et al., 2014; Kaspereit and Lopatta, 2016; Berthelot et al., 2012; Bachoo and Wilson, 2013). Furthermore, Mirza et al. (2019) stated that most research on value relevance in the early stages focused on developed countries. 
Indonesia, as a developing country, enacted a new POJK (Financial Services Authority Regulation) No.51 / 2017, which regulates the disclosure of sustainability reports, while other developing countries, Malaysia, have enacted regulations through the Sustainability Report Guidelines issued by the Bursa Malaysia, which became effective on December 31,2016. Based on these conditions, it can be interpreted that the sustainability report has been used for the capital market. Disclosure of information with outsiders on the non-economic influence of the company's business operations will reduce the possibility of the risk of information asymmetry between the company and its stakeholders. This can also reduce the potential for adverse regulatory pressures and make the company better in increasing the advantages of future investment opportunities (Chiu and Wang, 2015).

Therefore, we would like to explore the sustainability reporting of developing countries, Indonesia, and Malaysia. These countries provide different implementation arrangements for sustainability reports, which are mandatory in Malaysia and voluntarily in Indonesia. We chose these countries for several reasons. First, empirical evidence about Indonesia and Malaysia as developing countries is still scarce because reliable data is not available to date (Miralles-Quirós et al., 2018). Second, their social and cultural heritage are similar (Chapple and Moon, 2005). Third, a study in the relevance of the value of accounting information in emerging markets is They are attractive because investors in emerging markets still have minimal information (Alali, 2012).

\subsection{Hypothesis Development}

Sustainability reporting can reduce information asymmetry towards managers and investors by communicating its good performance to increase information transparency and enable investors to integrate sustainability information in stock valuations (Du et al., 2017). Previous studies have documented that sustainability reporting is useful for investors in making their investment decisions (Sutopo et al., 2018; Loh et al., 2017; Kuzey and Uyar, 2017; Lourenco et al., 2014). Therefore, sustainability reporting has a relevant value because it can make a difference in user decisions (Barth et al., 2001). 
Theoretically, sustainability reports are seen as quality voluntary signals to the market and prove that these companies are proactively passionate about managing their social and environmental risks (Malsch, 2013). Traditional signaling theory states that companies whose frequency is relatively rare to make disclosures or have lowquality disclosures can be considered that company is likely to hide information that is politically or economically unpleasant regarding their current performance or future risks (Akerlof, 1970). Therefore, high-quality companies will have more incentives to disclose their sustainability strategies, governance, and performance, which will be reflected in higher prices (Bachoo and Wilson, 2013).

Previous studies regarding the relevance of values to company disclosures still vary in results. Loh et al. (2017) explained that the better the quality of sustainability reporting, the stronger the relevance. Cortesi and Vein (2019) found that integrated reporting increased company disclosure and reduced information asymmetry. This means that reporting has value relevance. In contrast, Moneva and Cuellar (2009) found that non-financial reports are not significant for market valuations. Furthermore, Kaspereit and Lopatta (2016), using the Feltham and Ohlson assessment model, found.A significant relationship between GRI reporting and market value but not for all model specifications.

Involuntarily context study, Fazzini and DalMaso (2016) found that voluntary environmental disclosures can provide relevant valuation information to increase company value in Italy. Kuzey and Uyar (2017) also confirmed that sustainability reporting is value relevant in listed Turkish corporations. However, Moneva and Cuellar (2009) found that non-financial reporting, namely sustainability reporting, has no relevance value in the Spanish capital market. Miralles-Quiros et al. (2018) also showed that the market does not significantly value the three ESG pillars on sustainability report in Brazilian Case.

Meanwhile, in a mandatory context study, Tang and Zhong (2019) found that companies experienced a significantly lower possibility of a decline in share prices after mandatory sustainability reporting regulations were enacted. Lee and Yeo (2016) also found that firm valuation is positively associated with Integrated Reporting 
disclosures in South Africa. Moreover, Ioannou and Serafeim (2012) argue that companies in countries that implement sustainability reporting mandatorily demonstrate increased corporate governance. Companies adopt more ethical practices, decrease bribery and corruption, and increase managerial credibility. However, Bergmann and Posch (2018) found that mandatory regulations burden small companies compared to large companies.

Based on the signaling theory and explanation above, we consider sustainability reporting very important to increase the usefulness of the information and reduce information asymmetry in both mandatory and voluntary contexts. Thus, the hypotheses that can be formulated are as follows:

Hla: Sustainability reports in mandatory contexts (Malaysia) has value relevant. H1b: Sustainability reports involuntary context (Indonesia) has value relevant.

Research relating to the relevance of values and corporate disclosures is mostly limited to one context, mandatory or voluntary. However, there has been relatively little research that compares the relevance of the value of sustainability reporting between the two. A cross-country analysis study by Carnevale and Mazzuca (2014) states that the relevance of values of sustainability reports has varied results across European countries. This result is consistent with their hypothesis that the relevance of sustainability reports' values tends to be influenced by various institutions' context. Correspondingly, Aggarwal, and Singh (2018) argues that sustainability practices are significantly differed by dimensions/ categories, industry type, and company size but are not influenced by ownership structure.

Therefore, we want to fill the gap from previous research by comparing sustainability's value relevance in a mandatory and voluntary context. Another reason is that mandatory disclosure requirement are generally considered to be more capable of producing high-quality reporting, with voluntary disclosures generally found to be self-laudatory and incomplete (Situ and Tilt, 2018). We assume that mandatory and voluntary disclosures have different value relevance due to differences in the level of strictness of rules in sustainability reporting, which results in differences in the value of relevance. Thus, the hypotheses that can be formulated are as follows: 
H2: There are differences between Sustainability Reports about the relevance of values in the context of mandatory and voluntary disclosure in Malaysia and Indonesia.

\section{Research Method}

\subsection{Research Sample and Data}

Our samples are public firms with an ESG score on CSRHUB.com in 2019, which are 52 firms in Indonesia and 70 firms in Malaysia. We chose 2019 to represent the beginning year of the sustainability report as a mandatory report in Malaysia. We exclude listed financial firms for the final sample since they are regulated differently. A purposive sampling method is employed to obtain a sample of this study. Table 1 shows the sample selection procedure for this study. Based on the criteria used in the sample selection procedure, the final research sample was 43 firms in Indonesia and 57 firms in Malaysia. The number of final samples is relatively low due to the database's ESG score's data limitation.

Table 1.

Sample Selection Result

\begin{tabular}{lcc}
\hline \multicolumn{1}{c}{ Criteria } & $\begin{array}{c}\text { Indonesia } \\
\text { (Voluntary) }\end{array}$ & $\begin{array}{c}\text { Malaysia } \\
\text { (Mandatory) }\end{array}$ \\
\hline Initial sample & 52 & 70 \\
\hline Financial industry companies & $(9)$ & $(13)$ \\
\hline Final Sample & $\mathbf{4 3}$ & $\mathbf{5 7}$ \\
\hline
\end{tabular}

\subsection{Variables}

\subsubsection{Measurement}

We collect our financial data from Thomson Reuters Datastream. We use a price model that is an unbiased estimator (Kothari and Zimmerman, 1995; Cortesi and Vena, 2019) compared with the returned model. The price model's stock price reflects both historical information and surprising information cumulatively, so there is no bias in the price model regression (Kothari and Zimmerman, 1995). We use price close three months after the issuance of the policy on sustainability report. 
Figure 3.1

ESG Ranking Score

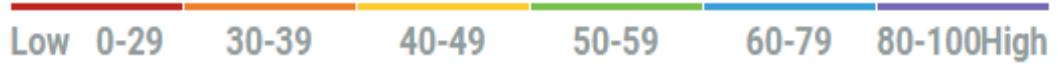

Source: $\underline{\text { csrhub.com }}$

We use the ESG ranking score to measure the sustainability report that obtained from https://www.csrhub.com. CSRHub is a web-based tool that provides employee, environmental, community, and governance ratings on the most prominent companies in North America, Europe, and Asia. CSRHub combines data from 10 of the premier socially responsible investment (SRI) analysis firms (also known as Environment, Social, Governance/ESG), and over 600 non-governmental organizations (NGOs), government agencies, news feeds, social networking groups, smaller for-profit organizations, and publishers. The value above shows, the higher the value, the better the value of the sustainability report.

\subsubsection{Model}

This study used Ohlson's Model (1995) to test the relevant accounting information: corporate earnings and book value of corporate equity. This study added variable Sustainability Report in Ohlson's model to test the effect of sustainability information in enhancing accounting information's value relevance. This study examined the value relevance of accounting information and sustainability using the price model. The formula of the regression equation in this research is:

$P=\propto+\beta_{1} E P S_{i t}+\beta_{2} B V S_{i t}+\beta_{3} E S G_{i t}+\beta_{4} T A_{i t}+\varepsilon_{i t}$

In the formula, where $P$ is the share price observed three months after the end of the fiscal year, EPS and $B V S$ denote the book value and earnings per share, respectively, of the $i$, the company. In case the coefficient $\beta 1$ and $\beta 2$ are found to be statistically different from zero, we may conclude that the accounting numbers to which they relate (EPS and BVS) are value relevant (Cortesi and Vena, 2019). This statistical association proves their quality, in that they represent a consistent part of the information set on which investors systematically rely to make their decisions. 
Sustainability Report $(S R)$ adoption reduces information asymmetries creating value for investors. We may observe a significant positive coefficient $\beta 3$ on the average share price of each group. The corresponding value indicated as ESG measures the relative/percentage impact of Sustainability Report adoption on companies' market value. The significance of ESG denotes that the adoption of $S R$ effectively increases the quality of reporting and creating value for investors. (Cortesi and Vena, 2019). We use the control variable $T A$ considers other exogenous factors, which may affect market price. Thus, we have included the company's total assets to model the size effect for the market value (Cortesi and Vena, 2019).

\section{Empirical Results}

\subsection{Descriptive Statistics and Correlation Analyzes}

Table 2.

Descriptives Statistics

\begin{tabular}{|c|c|c|c|c|c|c|}
\hline \multicolumn{7}{|c|}{ Sample: Indonesia listed firms } \\
\hline Variables & $\mathrm{N}$ & Mean & Median & Std. Dev. & Min & Max \\
\hline Price & 43 & $7.609,19$ & 2.350 & $15.013,68$ & 123 & 83.200 \\
\hline EPS & 43 & 84,89 & 19,69 & 222,28 & $-54,17$ & $1.224,13$ \\
\hline BVP & 43 & $2.591,05$ & 828,52 & $4.667,73$ & 0,01 & $24.681,08$ \\
\hline ESG & 43 & 50,28 & 50 & 4,76 & 42 & 59 \\
\hline TA & 43 & $5.662 .947,17$ & $5.186 .530,60$ & $4.001 .877,33$ & $38.334,19$ & $18.897 .513,06$ \\
\hline \multicolumn{7}{|c|}{ Sample: Malaysia listed firms } \\
\hline Variables & $\mathrm{N}$ & Mean & Median & Std. Dev. & Min & Max \\
\hline Price & 57 & 104.811 & 41.500 & 2.229 .308 & 0.19 & 146.8 \\
\hline EPS & 57 & 0.089 & 0.04 & 0.158126 & -0.04 & 1.000 \\
\hline BVP & 57 & 32.435 & 20.900 & 333.986 & 0.08 & 14.95 \\
\hline ESG & 57 & 53 & 53 & 5.574 & 37 & 67 \\
\hline TA & 57 & $6.575 .349,47$ & $93.991,72$ & $35.541 .876,93$ & $1.620,51$ & $234.453 .620,15$ \\
\hline
\end{tabular}

Price is the closed price of companies three months after the end of the fiscal year $(t)$; EPS is earnings per share in $t$; BVP is book value per share in $t$; ESG is sustainability report ratings; TA is the square root of shifted total assets.

Table 2 reports descriptive statistics for the variables employed for investigating $\mathrm{H} 1$ and H2. All variables (except assets and ESG score) are transformed to the rank 
case to mitigate outliers' effects. In descriptive statistics, the average stock price (Price) is 7,609, EPS 84.89, and BVP 2,591.05. Moreover, the average ESG score is 50.28 for the Indonesian sample. It shows that Indonesia's ESG value occupies the middle value on the CSRHUB Version of the ESG Score. The mean ESG score of Malaysia is not much different from Indonesia, which is 53. This shows that there is only a slight difference in scores shown by the sustainability report for Indonesia and Malaysia

Table 3 reports a Pearson Correlation matrix. A correlation matrix permits the measurement of the strength of the linear relationship between the variables. It shows earnings per share and book value per share are positively associated with price as expected, while ESG and TA do not correlate with price.

Table 3.

Correlation Matrix

\begin{tabular}{|c|c|c|c|c|c|}
\hline \multicolumn{6}{|c|}{ Indonesia listed firms } \\
\hline & Price & EPS & BVP & ESG & TA \\
\hline Price & - & $0.446 * *$ & $0.654 * *$ & .080 & .199 \\
\hline EPS & & - & $0.453 * *$ & -.261 & $.580 * *$ \\
\hline BVP & & & - & -.065 & $.397 * *$ \\
\hline ESG & & & & - & -28 \\
\hline TA & & & & & - \\
\hline
\end{tabular}

Malaysia listed firms

\begin{tabular}{llllll}
\hline & Price & \multicolumn{1}{c}{ EPS } & \multicolumn{1}{c}{ BVP } & \multicolumn{1}{c}{ ESG } & \multicolumn{1}{c}{ TA } \\
\hline Price & - & $.823^{* *}$ & $.445^{* *}$ & .2 & .007 \\
EPS & & - & $.410^{* *}$ & .102 & .093 \\
BVP & & & - & -.151 & .179 \\
ESG & & & & - & .115 \\
TA & & & & & - \\
\hline
\end{tabular}

Price is the square root of companies' closed price three months after the end of the fiscal year $(t)$; EPS is earnings per share in $t$; BVP is book value per share in $t$; ESG is sustainability report ratings; TA is total assets.

**: Correlation is significant at the 0,01 (2-tailed).

\subsection{Regression Result}

We examine whether information content on sustainability reporting is reflected in listed Malaysia and Indonesia companies' market prices with different policy contexts, voluntary (Indonesia) and mandatory (Malaysia). In Indonesia, the results of 
Table 4 show that earnings, book value per share, and ESG are each statistically significant at $5 \%, 1 \%$, and $10 \%$ level. The adoption of the sustainability report seems to influence also the value relevance of EPS and BVPS. The adjusted $\mathrm{R}^{2}$ of the model is $47 \%$.

Table 4.

Regression Result for Value Relevance of Sustainability Reporting

\begin{tabular}{|c|c|c|c|c|c|c|c|}
\hline \multicolumn{8}{|c|}{ Indonesia listed firms } \\
\hline \multicolumn{4}{|c|}{ Model Specifications } & \multicolumn{4}{|c|}{ Coefficient Estimates of Variables } \\
\hline $\mathrm{R}^{2}$ & $\mathrm{~F}$ & Sign. & $\mathrm{N}$ & EPS & PBV & ESG & TA \\
\hline 0.47 & 10.48 & 0.000 & 43 & $0,375 * *(2,49)$ & $0,597 * * *(4,67)$ & $0,55 *(1,78)$ & $-0,001 *(-1,76)$ \\
\hline \multicolumn{8}{|c|}{ Malaysia listed firms } \\
\hline \multicolumn{4}{|c|}{ Model Specifications } & \multicolumn{4}{|c|}{ Coefficient Estimates of Variables } \\
\hline $\mathrm{R}^{2}$ & $\mathrm{~F}$ & Sign. & $\mathrm{N}$ & EPS & PBV & ESG & TA \\
\hline 0.703 & 34 & 0 & 57 & $0.74 * * *(9,11)$ & $0.052 * *(2,26)$ & $0.166 * *(2,19)$ & $-114(-1,53)$ \\
\hline
\end{tabular}

Moreover, in Malaysia, the results of Table 4 show that earnings, book value per share, and ESG are each statistically significant at 1\%, 5\%, and 5\% level. The adjusted $\mathrm{R}^{2}$ of the model is $70 \%$. Those findings show that both earnings and book value in Indonesia and Malaysia are significantly associated with the stock price. Furthermore, ESG scores contributing positively to the market prices of adopting firms. Therefore, hypotheses $1 \mathrm{a}$ and $1 \mathrm{~b}$ are supported. The results of this study support the previous research studies, i.e., studies conducted by Sutopo et al. (2018); Loh et al., (2017); Kuzey and Uyar (2017) proving that sustainability reporting is relevant information to assess company both in mandatory and voluntary context. In other words, sustainability reports increase information transparency. Thus shareholders can consider sustainability information in stock valuation.

The variables in a model with greater adjusted $\mathrm{R}^{2}$ are more value-relevant (Cortesi and Vena, 2019; Kirkulak and Balsari, 2009). Since Malaysia's explanatory power is more significant than in Indonesia, the sustainability reporting in mandatory context is more value relevant than voluntary context. Therefore, the results provide empirical 
evidence of differences in value relevance of sustainability reporting in the context of mandatory and voluntary disclosure. Thus, hypothesis 2 is supported. A plausible interpretation of these results is that the mandatory disclosure requirement is expected to produce a higher-quality sustainability report because the reporting's content information might be more complete as a GRI requires. Higher-quality sustainability reports seem likely to boost the market value creation of listed firms.

\section{Conclusion, Implication, and Limitation}

\subsection{Conclusion}

In this study, we investigate the value relevance of the information contained on sustainability reporting by employed Ohlson's Model. Our research is conducted in Malaysia and Indonesia to represent a different context, which is mandatory and voluntary adoption. The results show that our study gives empirical evidence to support both $\mathrm{H} 1$ and $\mathrm{H} 2$ hypotheses. It means that sustainability reports in both the mandatory (Malaysian) and voluntary (Indonesian) context are relevant. Other than that, there is a difference in the relevance of sustainability reporting in the context of mandatory and voluntary disclosure. Our findings confirm the findings of prior studies conducted in developed markets such as the United States, European Countries, Canada, and Australia (Lourenco et al., 2014; Kaspereit and Lopatta, 2016; Berthelot et al., 2012; Bachoo and Wilson., 2013) and emerging market such as in Turkey, Brazil, Indonesia, and Malaysia (Kuzey and Uyar, 2017; Miralles-Quiros et al., 2018; Sarumpaet et al., 2017; Iatridis, 2013).

Overall, our evidence offers support to wider spread and mandatory adoption of sustainability reporting, as it gives benefits not only to the firms but also shareholders. Firms with high quality of sustainability reporting are expected to have a more positive image with stakeholders. Thus it could increase their market value. Shareholders are also expected to positively impact sustainability reporting because the report helps investors better evaluate the company's market value and reduce their uncertainty regarding the firm's future environment and social performance. 


\subsection{Limitation and Suggestions Research}

One limitation of this study was data limitations related to ESG scores in Malaysia and Indonesia firms. Thus, the number of samples used is relatively low. Therefore, further study could increase the sample by exploring other regions of the world that the listed firms must or voluntarily issue sustainability reporting. So, the results can be better generalized. Furthermore, we suggest adding control variables of the research, such as net sales standardized, total liabilities, inventory, and accounts receivable.

\section{References}

Aggarwal, P., \& Singh, A. K. (2018). CSR and sustainability reporting practices in India: An in-depth content analysis of top-listed companies. Social Responsibility Journal.

Alali, F. A., \& Foote, P. S. (2012). The value relevance of international financial reporting standards: Empirical evidence in an emerging market. The international journal of accounting, 47(1), 85-108.

Amir, E., Harris, T. S., \& Venuti, E. K. (1993). A comparison of the value-relevance of US versus non-US GAAP accounting measures using form 20 -F reconciliations. Journal of Accounting Research, 31, 230-264.

Aras, G., Tezcan, N., \& Kutlu Furtuna, O. (2018). The value relevance of the banking sector multidimensional corporate sustainability performance. Corporate Social Responsibility and Environmental Management, 25(6), 1062-1073.

Akerlof, G. (1970). The Market for "Lemons": Quality, Uncertainty, and the Market Mechanism. Quarterly Journal of Economics. 84, 3: 488 - 500.

Ball, R., \& Brown, P. (1968). An empirical evaluation of accounting income numbers. Journal of accounting research, 159-178.

Bachoo, K., Tan, R., \& Wilson, M. (2013). Firm value and the quality of sustainability reporting in Australia. Australian Accounting Review, 23(1), 67-87.

Barth, M. E., Beaver, W. H., \& Landsman, W. R. (2001). The relevance of the value relevance literature for financial accounting standard setting: another view. Journal of accounting and economics, 31(1-3), 77-104.

Bergmann, A., \& Posch, P. (2018). Mandatory Sustainability Reporting in Germany: Does Size Matter?. Sustainability, 10(11), 3904. 
Berthelot, S., Coulmont, M., Serret, V. (2012). Do investors value sustainability reports? A Canadian study. Corporate Social Responsibility and Environmental Management. 19(6), 355- 363

Carnevale, C., \& Mazzuca, M. (2014). Sustainability report and bank valuation: evidence from European stock markets. Business Ethics: A European Review, 23(1), 69-90.

Chapple, W., \& Moon, J. (2005). Corporate social responsibility (CSR) in Asia: A sevencountry study of CSR web site reporting. Business \& Society, 44(4), 415-441.

Chiu, T. K., \& Wang, Y. H. (2015). Determinants of social disclosure quality in Taiwan: An application of stakeholder theory. Journal of business ethics, 129(2), 379-398.

Cortesi, A., \& Vena, L. (2019). Disclosure quality under integrated reporting: A Value Relevance Approach. Journal of Cleaner Production, 220, 745-755.

Cotter, J., Lokman, N., \& Najah, M. M. (2011). Voluntary disclosure research: Which theory is relevant. The Journal of Theoretical Accounting Research, 6(2), 77-95.

Du, S., Yu, K., Bhattacharya, C. B., \& Sen, S. (2017). The Business Case for Sustainability Reporting: Evidence from Stock Market Reactions. Journal of Public Policy \& Marketing, 36(2), 313-330. https://doi.org.ezproxy.ugm.ac.id/10.1509/jppm.16.112

Fazzini, M., \& Dal Maso, L. (2016). The value relevance of "assured" environmental disclosure: The Italian experience. Sustainability Accounting, Management and Policy Journal, 7(2), 225-245.

Francis, J., \& Schipper, K. (1999). Have financial statements lost their relevance? Journal of Accounting Research, 37(2), 319-352. doi:10.2307/2491412

González, M., del Mar Alonso-Almeida, M., \& Dominguez, D. (2018). Mapping global sustainability report scoring: a detailed analysis of Europe and Asia. Quality \& Quantity, 52(3), 1041-1055.

GRI (Global reporting initiative). 2019. www.globalreporting.org accessed on September 3, 2019

Hahn, Rudiger \& Kuhnen, Michael. 2013. Determinants of sustainability reporting: a review of results, trends, theory, opportunities in an expanding field of research. Journal of Cleaner Production, 5-12

Hellström, K. (2006). The value relevance of financial accounting information in a transition economy: The case of the Czech Republic. European accounting review, 15(3), 325-349.

Holthausen, R. W., \& Watts, R. L. (2001). The relevance of the value-relevance literature for financial accounting standard setting. Journal of accounting and economics, 31(1-3), 375 .

Ioannou, I., \& Serafeim, G. (2012). The Consequences of Mandatory Corporate Sustainability Reporting. Working Paper, Harvard Business School. 
Iatridis, G. E. (2013). Environmental disclosure quality: Evidence on environmental performance, corporate governance, and value relevance. Emerging Markets Review, 14, $55-75$.

Kaspereit, T., \& Lopatta, K. (2016). The value relevance of SAM's corporate sustainability ranking and GRI sustainability reporting in the European stock markets. Business Ethics: A European Review, 25(1), 1-24. https://doi.org.ezproxy.ugm.ac.id/10.1111/beer.12079

Kerr, J. N. (2019). The value relevance of taxes: International evidence on the proxy for profitability role of tax surprise. Journal of Accounting and Economics, 67(2-3), 297-305.

Kirkulak, B., \& Balsari, C. K. (2009). Value relevance of inflation-adjusted equity and income. The International Journal of Accounting, 44(4), 363-377.

Kothari, S. P., \& Zimmerman, J. L. (1995). Price and return models. Journal of Accounting and Economics, 20(2), 155-192.

Kuzey, C., \& Uyar, A. (2017). Determinants of sustainability reporting and its impact on firm value: Evidence from the emerging market of Turkey. Journal of cleaner production, 143, 27-39.

Lee, K. W., \& Yeo, G. H. H. (2016). The association between integrated reporting and firm valuation. Review of Quantitative Finance and Accounting, 47(4), 1221-1250.

Loh, L., Thomas, T., \& Wang, Y. (2017). Sustainability reporting and firm value: Evidence from Singapore-listed companies. Sustainability, 9(11), 2112.

Lourenço, I. C., Callen, J. L., Branco, M. C., \& Curto, J. D. (2014). The value relevance of reputation for sustainability leadership. Journal of Business Ethics, 119(1), 17-28.

Malsch, B. (2013). Politicizing the expertise of the accounting industry in the realm of corporate social responsibility. Accounting, Organizations, and Society, 38(2), 149-168.

Miralles-Quirós, M., Miralles-Quirós, J., \& Valente Gonçalves, L. (2018). The value relevance of environmental, social, and governance performance: The Brazilian case. Sustainability, 10(3), 574.

Mirza, A., Malek, M., \& Abdul-Hamid, M. A. (2019). Value relevance of financial reporting: Evidence from Malaysia. Cogent Economics \& Finance, 7(1), 1651623.

Moneva, J. M., \& Cuellar, B. (2009). The value relevance of financial and non-financial environmental reporting. Environmental and Resource Economics, 44(3), 441-456.

Narullia, D., \& Subroto, B. (2018). Value relevance of accounting information and corporate social responsibility in Indonesia And Singapore. Jurnal Aplikasi Manajemen, 16(1), 919.

Ohlson, J. A. (1995). Earnings, book values, and dividends in equity valuation. Contemporary accounting research, 11(2), 661-687. 
Peraturan Otoritas Jasa Keuangan (POJK) No.51 Tahun 2017. Retrieved From https://www.ojk.go.id/id/kanal/perbankan/regulasi/peraturan-ojk/Documen

Sarumpaet, Susi \& Nelwan, Melinda \& Dewi, Dian. (, 2017). The value relevance of environmental performance: Evidence from Indonesia. Social Responsibility Journal. 13. 00-00. 10.1108/SRJ-01-2017-0003.

Situ, H., \& Tilt, C. (2018). Mandatory? Voluntary? A Discussion of Corporate Environmental Disclosure Requirements in China. Social and Environmental Accountability Journal, 38(2), 131-144.

Sustainability Reporting Guide $2^{\text {nd }}$ Edition. (, 2018). Bursa Malaysia. Retrieved from https://bursamalaysia.s3.amazonaws.com/reports/Bursa\%20Malaysia\%20Sustainability $\% 20$ Reporting\%20Guide\%20(2nd-Edition).pdf

Sutopo, B., Kot, S., Adiati, A., \& Ardila, L. (2018). Sustainability Reporting and value relevance of financial statements. Sustainability, 10(3), 678.

Tang, D. Y., \& Zhong, R. (2019). Mandatory Sustainability Disclosure and Stock Price Crash Risk. http://sfi.cuhk.edu.cn/uploads/paper/2019061208.pdf

Tarquinio, L., Raucci, D., \& Benedetti, R. (2018). An investigation of global reporting initiative performance indicators in corporate sustainability reports: Greek, Italian and Spanish evidence. Sustainability, 10(4), 897.

Verrecchia, R. E. (1983). Discretionary disclosure. Journal of accounting and economics, 5, 179-194. 
The Indonesian Journal of Accounting Research - Sept, Vol. 23, No.3, 2020

\section{intentionally blank}

